\title{
The effect of incorporating slurries on the transport of faecal coliforms
}

3 John N. Quinton ${ }^{1}$, Sean F. Tyrrel ${ }^{2 *}$ and María C. Ramos ${ }^{3}$,

4 Abstract

5 The contamination of surface waters with pathogenic microorganisms transported from fields

6 to which livestock slurries and manures have been applied is a serious environmental concern.

7 Rainfall simulation experiments were conducted to test the hypothesis that the incorporation

8 of slurry into the soil would reduce bacterial transport in overland flow. A sandy loam soil

9 was packed into soil flumes ( $2.5 \mathrm{~m}$ long $\mathrm{x} 1 \mathrm{~m}$ wide) at a bulk density of $1400 \mathrm{~kg} \mathrm{~m}^{-3}$. Cattle slurry was either spread onto the soil surface or uniformly incorporated into the soil at a rate

11 of $30 \mathrm{Mg} \mathrm{ha}^{-1}(7.5 \mathrm{~kg} / \mathrm{plot})$. Simulated rainfall was applied to the plots at an intensity of 70

$12 \mathrm{~mm} \mathrm{~h}^{-1}$, using a pressure irrigation sprinkler. Presumptive faecal coliform (PFCs)

13 concentrations were higher in the runoff from the surface applied treatment (concentration

14 range $1.9 \times 10^{4}-1.1 \times 10^{6} \mathrm{PFC} 100 \mathrm{ml}^{-1}$ ) than from the incorporated treatments

15 (concentration range $6.0 \times 10^{3}-8.7 \times 10^{5} \mathrm{PFC} 100 \mathrm{ml}^{-1}$ ). Rates of transport of organic sediment and PFCs were highest in the initial phase of each experiment and declined as the simulation proceeded. The transport of PFCs and organic sediment were strongly correlated (values of $\mathrm{r}$ ranged from $0.72-0.91$ ), although there was considerable variation in this relationship from one experimental run to another. The implications of these findings for the protection of surface waters from pollution by bacterial contaminants are considered.

${ }^{1}$ Department of Environmental Science, Institute of Environmental and Natural Sciences, Lancaster University, Lancaster,LA1 4YQ, United Kingdom

${ }^{2}$ Institute of Water and Environment, Cranfield University, Silsoe, Bedford MK45 4DT United Kingdom *Corresponding author (s.tyrrel@ cranfield.ac.uk, tel: +44 1525863293 , fax: +44 1525863344

${ }^{3}$ Department of Environment and Soil Science, University of Lleida, Alcalde Rovira Roure 177, E-25198, Lleida, Spain 


\section{Key words}

Slurry, Faecal Coliforms, Pathogen transport, Overland Flow, Slurry Management, Diffuse pollution

\section{Introduction}

About 90 million tonnes of livestock slurry and manure are produced annually in the UK and this represents a significant resource for nutrient recycling via land application (Smith et al. 2001). However, the benefits of waste recycling may be partially offset by the risk of water pollution associated with runoff from fields to which slurry or manure has been applied (MAFF, 1998). In addition to the pollution threat posed by chemical components of animal faecal wastes such as readily biodegradable organic compounds, ammoniacal nitrogen and other nutrients, a proportion of livestock slurries and manures also contain pathogens such as Listeria, Campylobacter, Salmonella, E. coli 0157, Cryptosporidium, and Giardia (Nicholson et al., 2000). Thus, the contamination of surface waters with runoff from fields to which livestock wastes have been applied may lead to humans being exposed to such microorganisms via several routes. Examples include exposure to livestock waste derived pathogens via: drinking water (Ongerth and Stibbs, 1987; Hansen and Ongerth, 1991; Poulton et al., 1991; Skerrett and Holland, 2000); bathing waters (Geldreich, 1996; Wyer et al., 1996; Baudart et al., 2000); and water used for the irrigation of ready to eat foods (Tyrrel, 1999). Given the potential impacts of surface water contamination by faecal organisms, managing the application of slurries and manures to soils to prevent the bacterial contamination of surface waters is of obvious importance.

Overland flow is an important pathway for the transport of pathogens to water and there is no shortage of work describing this, see for example Caskey et al., (1971); Reddy et al., (1981); Crane et al., (1983); Sherer et al., (1992); Coyne and Blevins, (1995); Daniel et al., (1995); 
Mawdsley et al., (1996); Yeghiazarian and Montemagno, (2000), although there are contradictions. One debate centres on whether or not incorporation or injection will reduce pathogen losses. Daniel et al. (1995) found no significant differences in pathogen losses between surface applied and incorporated manure. Similar findings are reported by McCaskey et al. (1971) and Heinonen-Tanski and Uusi-Kämppä (2001) for injected and surface applied manures. We believe that these contradictory findings are due to the die off an growth of bacteria within the soil or on its surface prior to a runoff event, and that the incorporation of slurrues and manures will reduce the availability of bacteria for transport in overland flow if all other factors are constant. Our work therefore tests the hypotheses that the incorporation of slurries will lead to a reduced number of bacteria being detached and transported over the soil surface.

\section{Material and methods}

The study was performed in the laboratory using soil flumes set at a $5 \%$ slope. The flume (Fig. 1) were $2.5 \mathrm{~m}$ long, $1 \mathrm{~m}$ wide (across slope) and $30 \mathrm{~cm}$ deep, with a mesh screen located at the bottom of the slope to retain the soil, to allow drainage and thus to avoid the creation of saturated conditions.

Simulated rainfall was applied to the plots at an intensity of $70 \mathrm{~mm} \mathrm{~h}^{-1}$, using a pressure irrigation sprinkler. We chose a high intensity storm to represent extreme conditions: a storm of this intensity for 15 minutes is estimated, using the method of Faulkner (1999) as having a return period of 14 years for Bedfordshire, in Southern England. The sprinkler had a nozzle (LECHLER GMbh 56072830-CE) positioned $2 \mathrm{~m}$ above the soil surface. Raindrop size ranged between $0.7 \mathrm{~mm}$ and $2.8 \mathrm{~mm}$, with a $\mathrm{D}_{50}$ value of $1.2 \mathrm{~mm}$.

4 A sandy loam textured soil (Table 1) of the Cottenham series defined by Clayden and Hollis (1984) and classified as Lamellic Ustipsamment (Soil Survey Staff, 1999) was used 
throughout the experiments. The soil was passed through a $9.5 \mathrm{~mm}$ sieve and packed into the flume at a bulk density of about $1400 \mathrm{~kg} \mathrm{~m}^{-3}$. One day prior to each runoff experiment, the erosion plot was exposed to simulated rainfall, whilst protected with fabric to avoid soil detachment, and allowed to drain for 24 hours to give an initial soil moisture content close to field capacity.

Cattle slurry from a local dairy farm was applied to the soil at a rate of $30 \mathrm{Mg} \mathrm{ha}^{-1}(7.5$ $\mathrm{kg} / \mathrm{plot}$ ), which is below the maximum value recommend (MAFF, 1998) and represents a normal application rate for many arable farmers in the UK. The dry solids content of the slurry ranged from $8-24 \%$. Prior to application the number of presumptive faecal coliforms (PFCs) present in the slurry was enumerated. Ten g of moist slurry was added to $200 \mathrm{~mL}$ of sterile water and placed on a mechanical shaker for $20 \mathrm{~min}$. This solution was serially diluted prior to enumeration of PFCs by membrane filtration (APHA, 1992). The result was expressed on a weight basis of slurry.

The soil slope was exposed to simulated rainfall within $24 \mathrm{~h}$ of the slurry application. For each simulation the time to runoff was recorded and then samples were taken every five minutes until runoff had reached a constant value. The sediment concentration was determined gravimetrically for each sample. The organic matter content of the sediment was determined by loss after ignition in a furnace at $550{ }^{\circ} \mathrm{C}$ for $4 \mathrm{~h}$. One aliquot of each runoff sample was separated for the microbiological analysis. This was analysed in triplicate following serial dilution by membrane filtration (APHA, 1992).

\section{Results}

Statistical analysis using the Kolmogorov-Smirnov test revealed that there was no significant difference $(p<0.1)$ between the mean total runoff volume from the incorporated and surface applied plots during the 45 minute sampling period (Table 2). The total mass of mineral 
sediment transported was highest in the incorporated treatment whereas the total mass of

101 organic sediment transported was highest in the surface applied treatment (Table 2). These differences between the concentrations of mineral and organic sediment in runoff from the two treatments were significant at the $\mathrm{p}<0.1$ level. Mineral sediment concentrations were

104 generally stable for both treatments throughout the duration of the experiment (Figure 2). All

105 replicates are presented in this, and subsequent figures as samples were not taken at identical

106 times and the results could not therefore be averaged. Although the three replicates for the surface applied treatment behaved similarly, one of the replicates for the incorporated treatment was inexplicably different from the other two. Differences were also observed in the concentrations of organic sediment in the runoff from the two treatments (Figure 3). Organic

110 sediment concentrations were generally higher in the first 20 minutes of the experiment after 111 which the concentrations were broadly similar for the two treatments. Organic sediment concentrations declined more gradually in the runoff from the incorporated plots and were

113 generally less variable than in the runoff from the surface applied plots. The higher rate of 114 organic sediment transport from the surface applied plots was also reflected in the mean total 115 mass of organic sediment transported during the experiment (Table 2). The effect of simulated 116 rainfall on the transport of faecal coliforms from the runoff plots can be seen in Figure 4. To 117 account for variations in the initial faecal bacterial load of the batches of slurry used for the 118 incorporated and surface applied experiments, the data have been normalised by calculating 119 the ratio of the number of faecal coliforms $100 \mathrm{~mL}^{-1}$ runoff to the number of faecal coliforms

$120 \mathrm{~g}^{-1}$ slurry. This analysis suggests that faecal coliforms were very mobile in the first fifteen 121 minutes of the surface applied experiments but that this rate of transport declined rapidly as 122 the simulation progressed. Faecal coliforms were much less readily transported in runoff from 123 the incorporated treatment, and a gradual decline in the rate of faecal coliform transport was 124 observed throughout the duration of the experiment. 
126 The results indicate that the method of slurry application affected the dynamics of sediment

127 and faecal bacterial transport. Surface application of slurry led to higher concentrations in

128 runoff of both organic sediment and PFCs when compared to the incorporated treatment. As

129 the surface applied slurry was exposed to the erosive forces of rainsplash and overland flow

130 one would expect the organic matter particles and faecal organisms to be readily detached and

131 transported. Conversely, mineral sediment erosion was suppressed when slurry was surface

132 applied. This is probably explained by the protective effect that the layer of slurry had on the

133 soil surface. The results corroborate our initial hypothesis that the incorporation of slurry will

134 reduce the numbers of PFCs transported by reducing the number of organisms exposed to

135 detachment processes.

136 There were similarities in the pattern of transport of PFCs and organic matter in both the

137 surface applied and incorporated experiments i.e. losses were greatest in the initial part of the 138 storm followed by a decline in concentration as the experiment proceeded. This pattern was

139 most pronounced when the slurry was surface applied. The relationship between faecal

140 coliform and organic sediment concentrations in runoff for the incorporated and surface

141 experiments is shown in Figures 5 and 6 respectively. Although there is apparently a strong

142 correlation between these variables, there is substantial variation between experimental runs

143 in the values of the slope and intercept of the regression lines and the factors responsible for

144 this variation have not yet been elucidated. The PFC concentrations in the batches of slurry

145 used for each experiment did vary but this alone does not appear to account for the differences

146 in PFC concentration in the runoff. The percentage of dry matter was also very variable. It is

147 possible that the batches of slurry used in each experiment varied in terms of the partitioning

148 of PFCs between organic matter particle surfaces and cells/cell aggregates disassociated from 149 these particles. 
150 The decline in organic sediment transport as each experiment proceeded is in contrast to the

151 relatively stable rates of mineral sediment transport throughout the six experimental runs.

152 This suggests that in the initial stages of each storm organic slurry particles were

153 preferentially removed from this soil surface. As the storm proceeded more resistant material

154 was left behind and rates of transport fell. Such a process has been modelled by Rose and his

155 co workers (Hairsine and Rose, 1991; Rose et al., 1994; Sander et al., 1996) and

156 demonstrated experimentally for soil erosion (Heilig et al., 2001), whereby finer material is

157 removed leaving a more resistant layer of coarse particles, causing detachment rates to decline

158 through time. Our results suggest that if the transport of organic particles derived from

159 manure and slurry is to be modelled a similar approach will be required.

\section{Conclusions}

161 We conclude that a greater proportion of applied PFCs is transported from surface applied

162 than from incorporated slurries, and that this declines with time due the initial removal of

163 easily detached material leaving behind material that is more resistant to detachment. This

164 gives us an important insight into how microorganisms are detached and transported from soil

165 surfaces and indicates that the process may be modelled in the future. Furthermore, our

166 findings indicate that the transport of faecal microorganisms is correlated to the transport of

167 organic sediment particles. The number of PFCs per unit of organic sediment transported

168 varied considerably from one experiment to another. The range of faecal coliform

169 concentrations in the runoff from these experiments $\left(6.0 \times 10^{3}-1.1 \times 10^{6} \mathrm{PFC} 100 \mathrm{ml}^{-1}\right)$

170 represents a very significant risk to surface water pollution.

171 The contradictory evidence in the literature over whether or not the incorporation of slurries

172 and manures reduces the faecal pollution of water courses appears to be due to the survival of

173 bacteria once applied to the soil. Our view is that where possible slurries and manures should 
174 be incorporated since this reduces the risk of movement in overland flow, thus reducing the

175 risk of water pollution. Since it is likely that pathogenic bacteria will survive within the soil

176 after application, all steps should be taken to reduce the pathogenic content of the manure or

177 slurry prior to application.

\section{Acknowledgement}

179 Financial support for the project has been provided by the Biotechnology and Biological

180 Sciences Research Council (BBSRC); grant number 63/MAF12260.

181

182

183

184

185

186

187

188

189

190

191

192

193

\section{References}

APHA. American Public Health Association. 1992. Standard methods for the examination of water and waste water. $18^{\text {th }}$ ed. Washington, DC.

Baudart J., J. Grabulos, J-P. Barusseau, and P.Lebaron 2000. Salmonella spp. and fecal coliform loads in coastal waters from a point vs. non-point source of pollution. J. Environ. Qual. 29: 241-250.

Clayden, B., and J.M. Hollis. 1984. Criteria for Differentiating Soil Series. Soil Surv. Tech. Monogr. No. 17, pp. 159. Harpenden, UK.

Coyne M.S. and R.L. Blevins. 1995. Fecal bacteria in surface runoff from poultry manured fields. In K.Steele (ed.) Animal waste and the land-water interface Lewis publishers, University of Florida. pp 77-87

Crane S.R., J.A. Moore, M.E. Grismer, and J.R. Miner. 1983. Bacterial pollution from agricultural sources: a review. Trans. ASAE 26:858-866,872. 
194 Daniel T.C., D.R. Edwards, and D.J. Nichols. 1995. Edge of field losses of surface applied

195 manure. p89-98. In K. Steele (ed.) Animal waste and the land-water interface Lewis

196 publishers, University of Florida.

197 Faulkner, D. 1999. Rainfall frequency estimation. In "Flood Estimation Handbook", Vol. 2,

198 pp. 110. Inst. of Hydrology, Wallingford.

199 Geldreich E.E. 1996. Pathogenic agents in freshwater resources. Hydrol. Proc. 10: 315-333.

200 Hairsine P.B., and C.W. Rose. 1991. Rainfall detachment and deposition: sediment transport 201 in the absence of flow driven processes. Soil. Sci. Soc. Am. J. 55: 3230-324.

202 Hansen, J.S. and J.E. Ongerth, 1991. Effects of time and watershed characteristics on the 203 concentration of Cryptosporidium oocysts in river water. Appl. Environ. Microbiol. 57: $204 \quad 2790-2795$.

205 Heilig A., D. DeBruyen, M.T. Walter, C.W. Rose, J-Y. Parlange, T.S. Steenhuis, G.C.

206 Sander, P.B. Hairsine, W.L. Hogarth, and L.P. Walker. 2001. Testing a mechanistic soil 207 erosion model with a simple experiment. J. Hydrol. 244: 9-16.

208 Heinonen-Tanski H. and J.Uusi-Kämppä. Runoff of faecal microorganisms and nutrients from 209 perennial grass ley after application of slurry and mineral fertiliser. Water Sci. Technol. 43: $210 \quad 143-146$.

211 MAFF (1998) Code of good agricultural practice for the protection of water. MAFF 212 Publications, London (Second edition).

213 McCaskey T.A., G.H. Rollins, and J.A. Little. 1971. Water quality of runoff from grassland 214 applied with liquid, semi-liquid and dairy 'dry' waste. pp 239-242. In Livestock waste 215 management and pollution abatement. Proceedings of the International Symposium on 

Engineering Publication PROC-271. St. Joseph, Michigan.

218 Nicholson, F.A., M.C., Hutchison, K.A., Smith, C.W., Keevil, B.J., Chamber and A.Moore. 219 2000. A study on farm manure application to agricultural land and an assessment of the 220 risks of pathogens transfer into the food chain. MAFF.

221 Mawdsley, J.L., A.E. Brooks, and R.J. Merry. 1996. Movement of the protozoan pathogen 222 Cryptosporidium parvum through three contrasting soil types. Biol. Fertil. Soils. 21:30-36.

223 Ongerth, J.E. and H.H. Stibbs, (1987) Identification of Cryptosporidium oocysts in river 224 water. Appl. Environ. Microbiol. 53:672-676.

225 Poulton, M., J.Colbourne, and P.J. Dennis, (1991) Thames Water's experience with 226 Cryptosporidium. Water Sci. Technol. 24: 21-26.

227 Reddy K.R., R. Khaleel, M.R. Overcash. 1981. Behaviour and transport of microbial 228 pathogens and indicator organisms in soils treated with organic wastes. J. Environ. Qual. 10 $229: 255-266$

230 Rose, C.W., W.L. Hogarth, G. Sander, I. Lisle, P. Hairsine, J-Y. Parlange. 1994. Modeling 231 processes off soil erosion by water. Trends. Hydrol. 1: 443-451.

232 Sander, G.C., P.B. Hairsine, C.W. Rose, D. Cassidy, J-Y. Parlange, W.L. Hogarth, and I.G. 233 Lisle. 1996. Unsteady soil erosion model, analytical solutions and comparison with 234 experimental results. J. Hydrol. 178: 351-367.

235 Sherer B.M., J.R. Miner, J.A. Moore, and J.C. Buckhouse. 1992. Indicator bacterial survival 236 in stream sediments. J. Environ. Qual 21:591-595. 
237 Skerrett, H.E. and C.V. Holland. 2000. The occurrence of Cryptosporidium in environmental 238 waters in the greater Dublin area. Water Res. 34. 3755-3760.

239 Smith, K.A., A.J. Brewer, J. Crabb, and A.Dauven. 2001. A survey of the production and use 240 of animal manure. Soil Use Manage. 17: 77-87.

241 Soil Survey Staff. 1999. Soil Taxonomy. A basic system of Soil Classification for Making 242 and Interpreting Soil Surveys (Second Edition). United States Department of Agriculture, 243 Natural Resources Conservation Service, Washington, USA.

244 Tyrrel, S.F. 1999. The microbiological quality of water used for irrigation. Irrigation News $245 \quad 27: 39-42$.

246 Wyer M.D., D. Kay, H.M. Dawson, G.F. Jackson, F. Jones, J. Yeo, and J. Whittle. 1996. 247 Delivery of microbial indicator organisms to coastal waters from catchment sources. Water $248 \quad$ Sci. Technol. 33: 37-50.

249 Yeghiazarian L.L., and C.D. Montemagno. 2000. Incorporation of the Water Erosion 250 Prediction Project (WEPP) in the modeling of the transport of pathogenic microorganisms 251 from non-point sources of pollution. p. 127-130. In Ascough II J.C. and D.C. (Eds) Soil 252 Erosion Research for the 21st Century. Proc. Int. Symp. 3-5 January 2001, Honolulu, HI, $253 \quad$ USA. Flanagan St. Joseph, MI: ASAE. 701P0007. 

Table 1. Particle size distribution of the Cottenham series soil used in the experiments

\begin{tabular}{ll}
\hline Soil property & Value \\
\hline Percent coarse sand $(>600 \mu \mathrm{m})$ & 1.7 \\
Percent medium sand $(212-600 \mu \mathrm{m})$ & 44.9 \\
Percent fine sand $(63-212 \mu \mathrm{m})$ & 36.3 \\
Percent silt $(2-63 \mu \mathrm{m})$ & 9.7 \\
Percent clay $(<2 \mu \mathrm{m})$ & 5.9
\end{tabular}

Table 2 Mean total runoff, mineral and organic sediment loss from the incorporated and surface applied slurry treatments during a 45 minute sampling period \pm standard deviation $(*$ indicates significant difference $[\mathrm{p}<0.1])$

\begin{tabular}{lcc}
\hline & Incorporated & Surface \\
\hline Mean total runoff (L) & $105 \pm 7$ & $101 \pm 10$ \\
Mean total mineral & $1023 \pm 546^{*}$ & $148 \pm 29^{*}$ \\
sediment eroded (g) & $126 \pm 20^{*}$ & $199 \pm 20^{*}$ \\
Mean total organic & & \\
sediment eroded (g) & & \\
\hline
\end{tabular}




\section{List of figure captions}

Fig. 1. Diagrammatic representation of the soil flume used in the experiments.

Fig 2. Mineral sediment lost from the soil slope for the incorporated and surface applied slurry treatments.

Fig 3. Organic sediment lost from the soil slope for the incorporated and surface applied slurry treatments.

Fig 4. Normalised presumptive faecal coliforms lost from the soil slope for the incorporated and surface applied slurry treatments.

Fig 5. Relationship between the concentrations of presumptive faecal coliform and organic sediment in the runoff from the incorporated experiments.

Fig 6. Relationship between the concentrations of presumptive faecal coliform and organic sediment in the runoff from the surface applied experiments. 
Fig. 1. Diagrammatic representation of the soil flume used in the experiments.

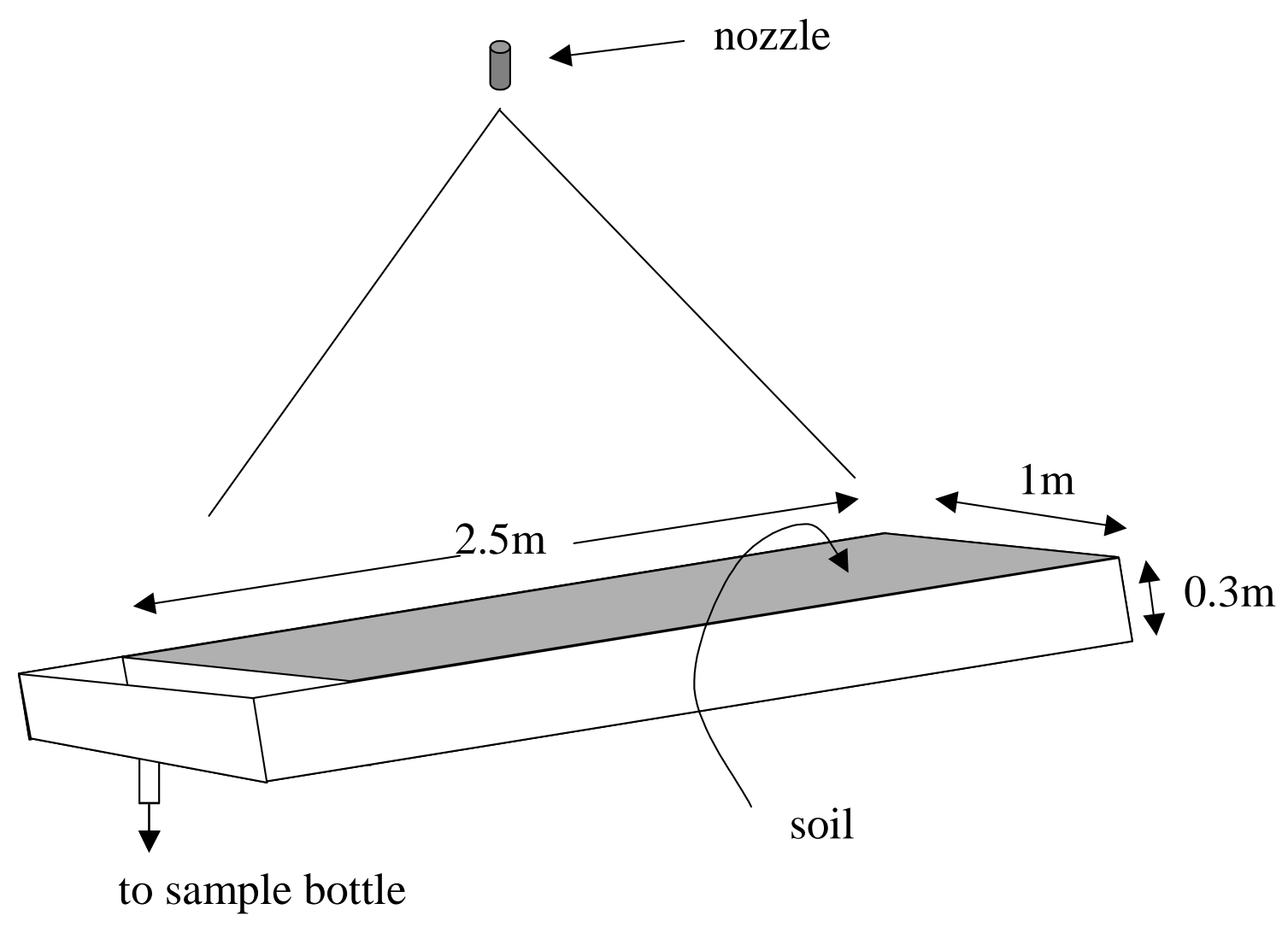


Fig 2. Mineral sediment lost from the soil slope for the incorporated and surface applied slurry treatments.

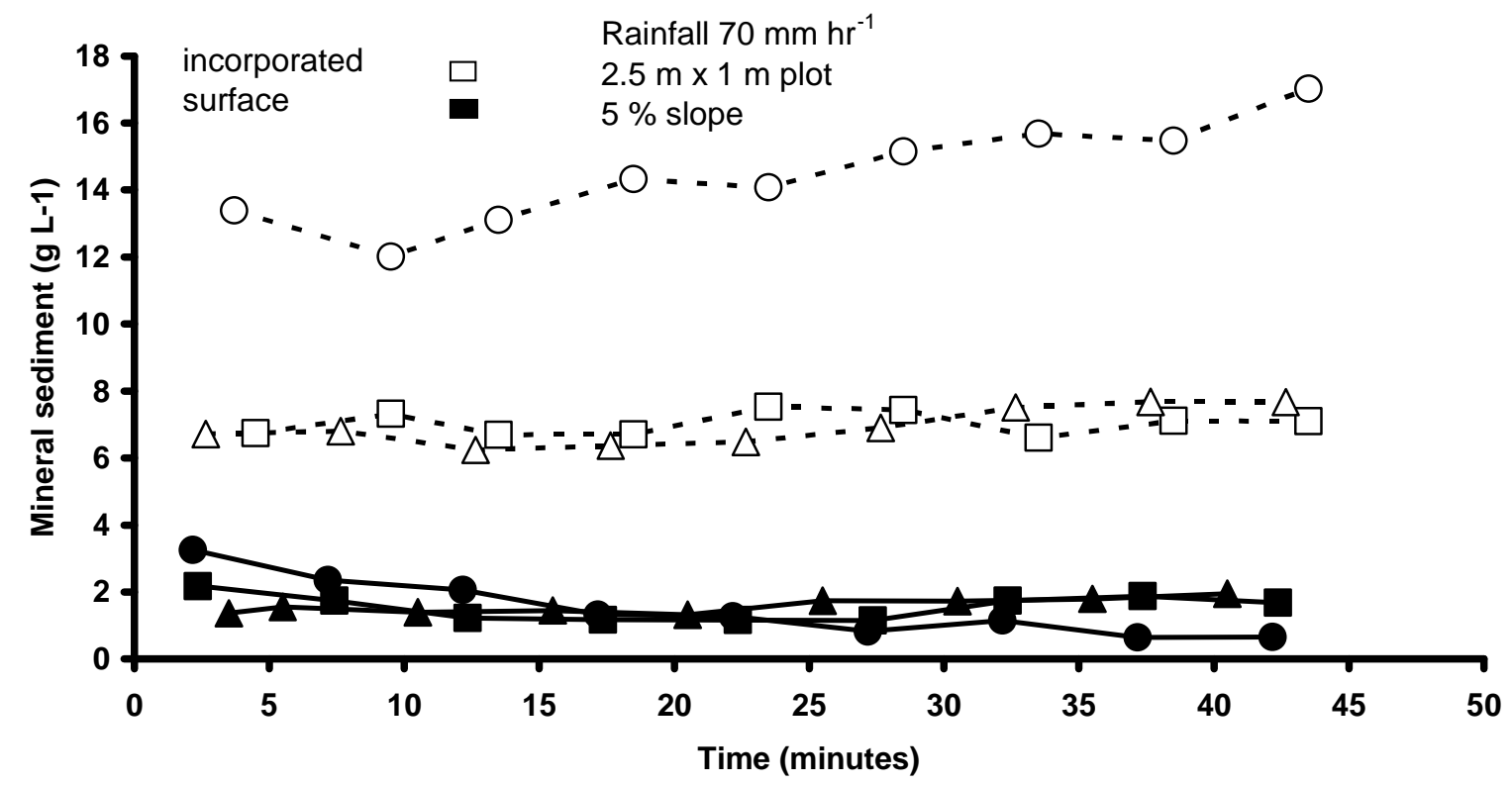


Fig 3. Organic sediment lost from the soil slope for the incorporated and surface applied slurry treatments.

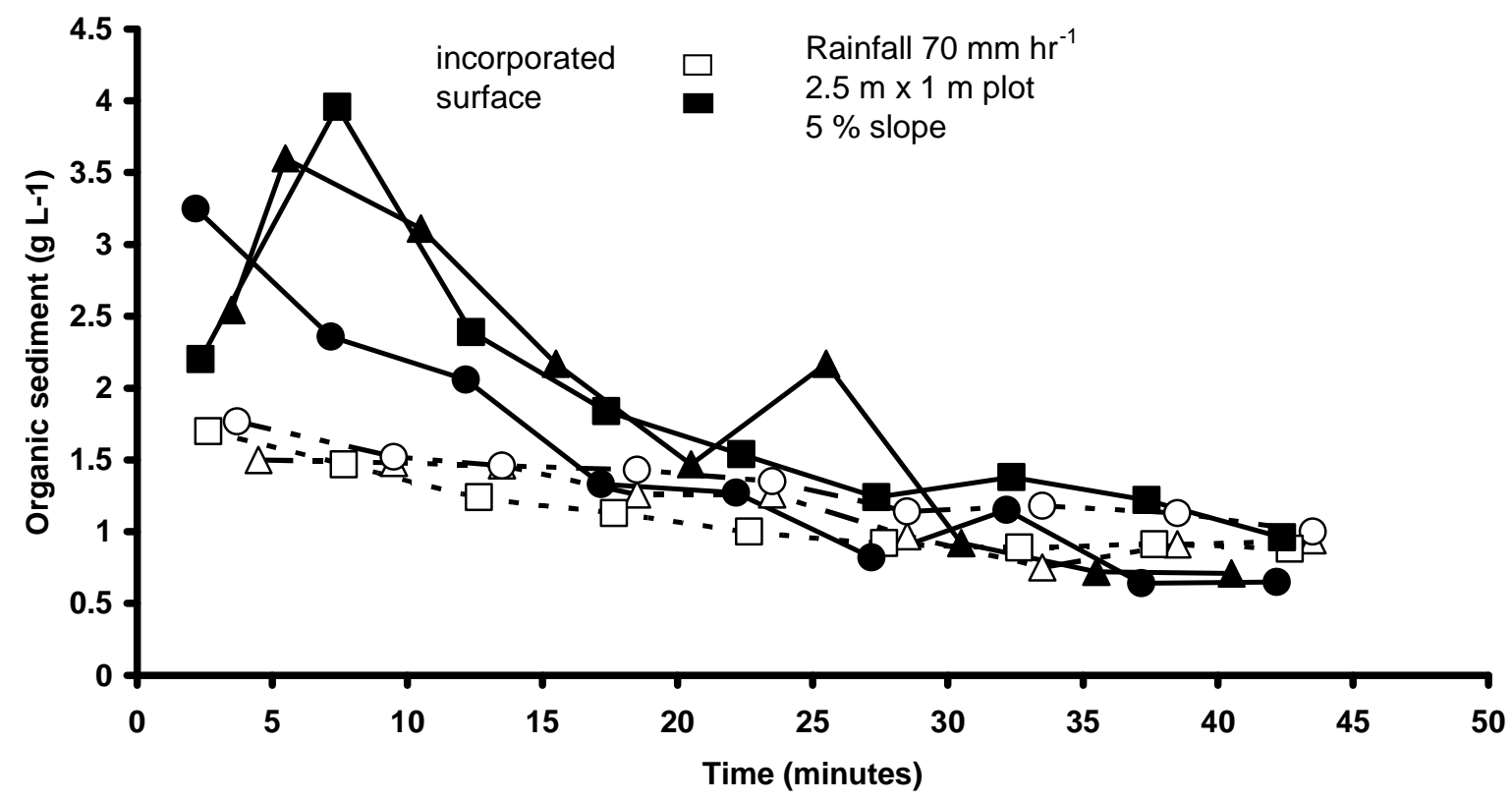


Fig 4. Normalised presumptive faecal coliforms lost from the soil slope for the incorporated and surface applied slurry treatments.

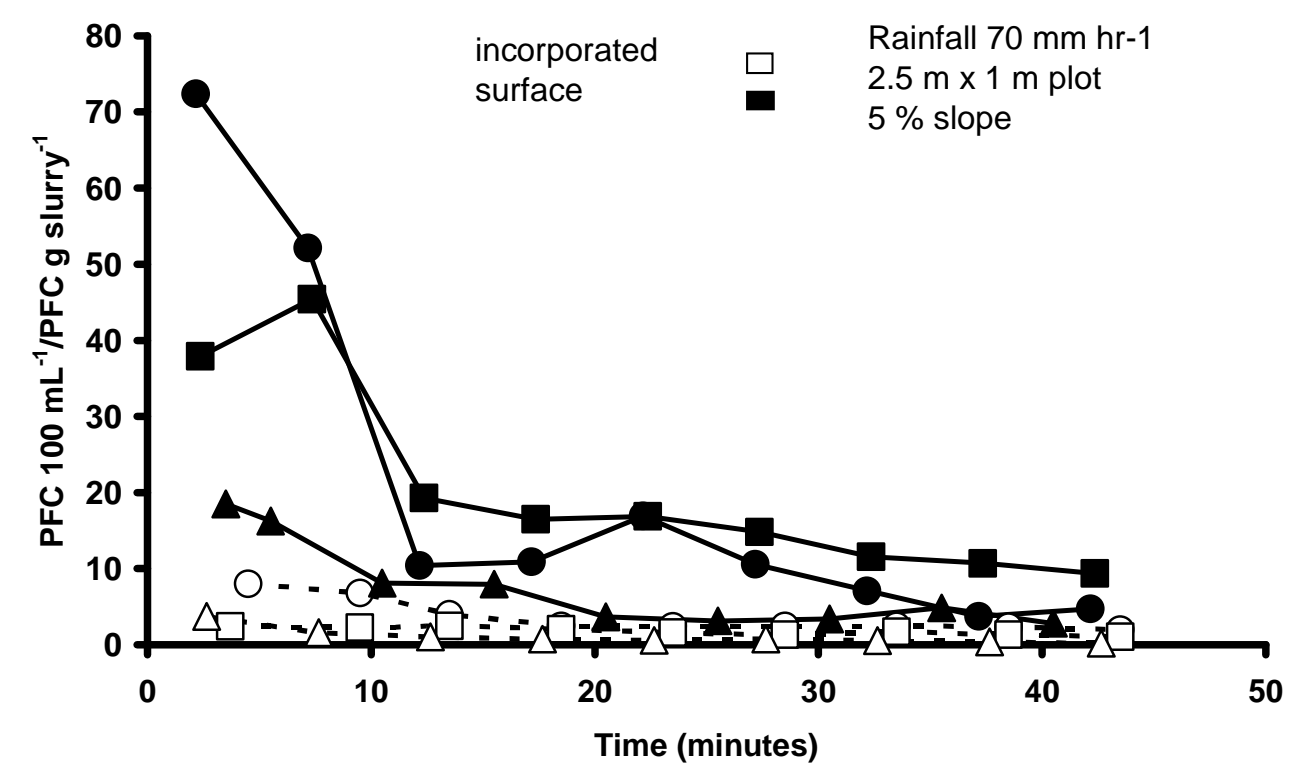


Fig 5. Relationship between the concentrations of presumptive faecal coliform and organic sediment in the runoff from the incorporated experiments

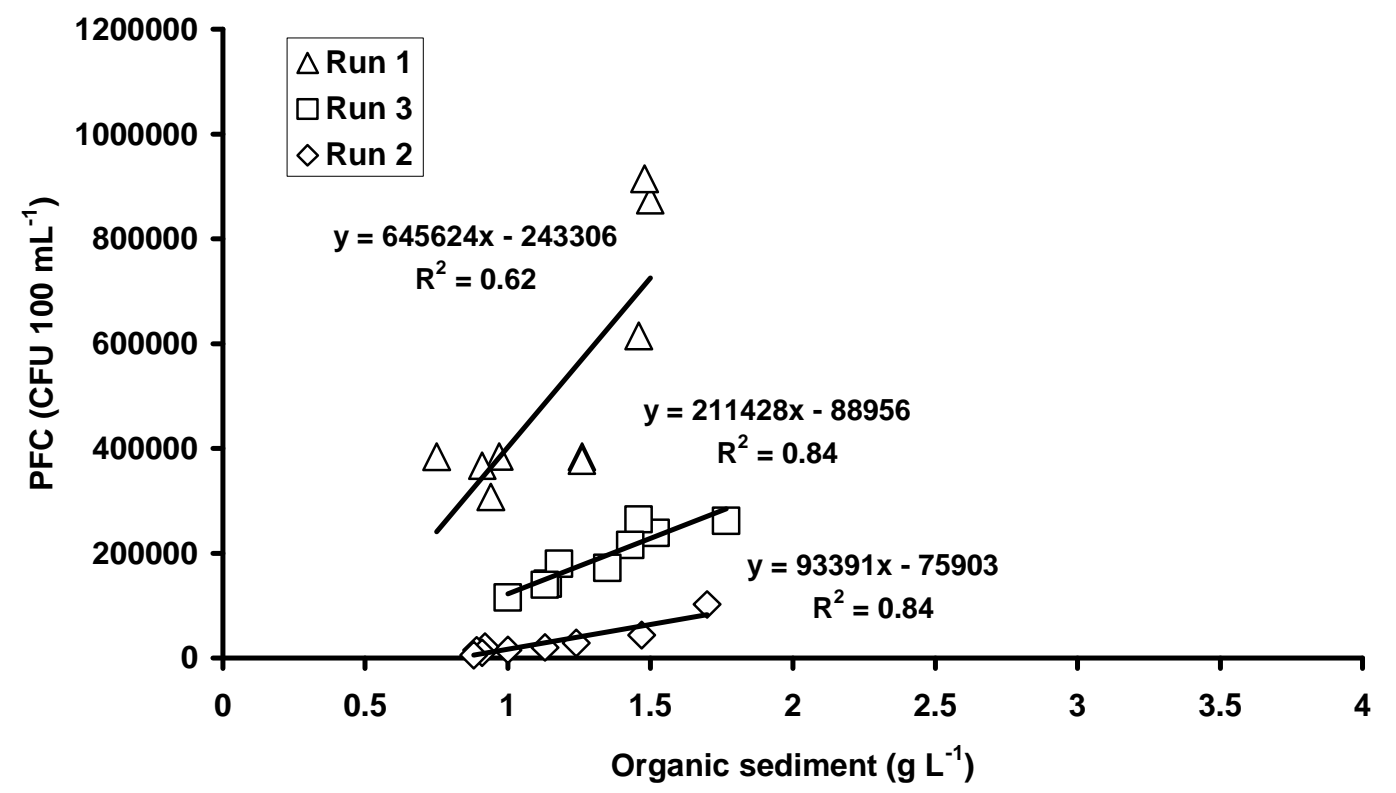


Fig 5. Relationship between the concentrations of presumptive faecal coliform and organic sediment in the runoff from the surface applied experiments

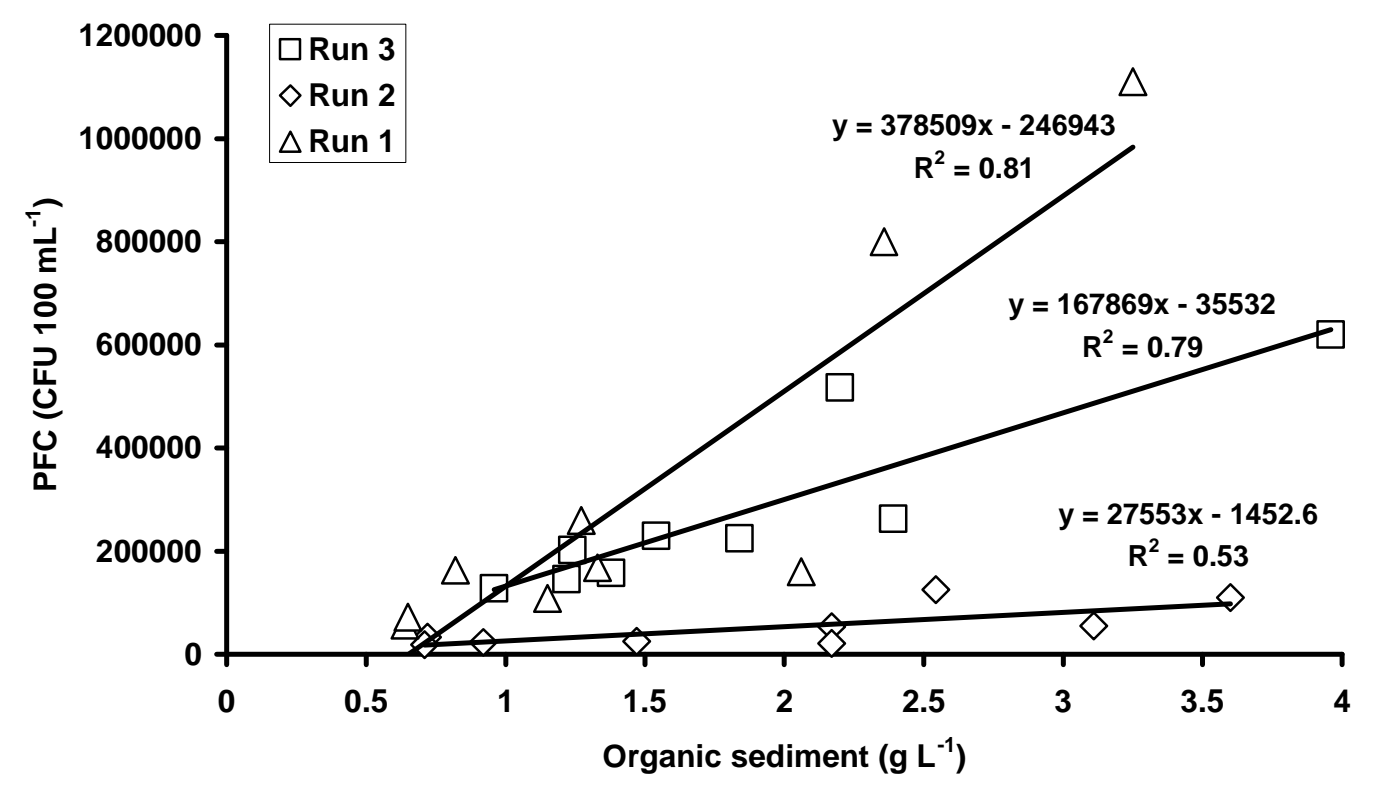

